\title{
Activity Driven Teaching Model for Software Project Management Course
}

\author{
S. Suguna Mallika \\ CVR College of Engineering, Department of CSE, Ibrahimpatan, R.R.District, A.P., India. \\ Email: suguna.kishore@gmail.com
}

\begin{abstract}
The objective of this paper is to introduce a cognitive learning methodology for the course Software Project Management. The industry realizes every year the need to train its managers in software project management and invests in the training costs though it a known fact that almost all the managers have undergone a course on Software Project Management either at their graduate level or post graduate level. On the other hand the teachers who teach software project management in class find it extremely challenging in sustaining the interest of the students all through the coursework. One obvious reason for this is the lack of real time exposure to live environments in which the industry operates and of course lack of experience of students in the area of management.

In an attempt to bridge this gap at least to a certain extent an activity driven teaching model has been proposed in this paper. This paper is aimed at stressing the importance of exposing the students to live case studies and thereby encouraging them in resolving some of the issues posed by the case study. The solutions can be discussed with the students thereof which would lead them realizing the standard practices explained theoretically in the prescribed text book. In this paper one such activity conducted to the students and their responses and how those responses could be traced back to the concepts explained in the text book has been illustrated.

An activity driven teaching model for SPM not only sustains the interest of the students with active interaction from them but also reduces the burden on the heavy training costs incurred by the industry in training the future managers.
\end{abstract}

Index Terms-SPM, Teaching methodology, cognitive learning.

\section{INTRODUCTION}

SPM is a course designed at the Bachelors level with an intension to enhance the employable skills of the students and bridge the hiatus between industry and institution. The concepts narrated in the course help in making the student aware of the contemporary industry standards and unlearn the myths of project management. Though the course is aimed at throwing light on some of the most important aspects of management, as it needs a lot of practical knowledge which the students lack the overall teaching effect could become ineffective. An attempt has been made to try and make teaching SPM more effective and interesting by engaging an activity driven model. One of the activities conducted to present a concept called Barry Boehm's Staffing Principles has been presented in this paper as an example for illustrating the effectiveness of the model.

\section{COGNITIVE LEARNING THEORY}

Bruner said anybody can learn anything at any age, provided it is stated in terms they can understand. Cognitivism is currently the predominant perspective within which human learning is described and explained. Contemporary cognitivism emphasizes mental processes and proposes that many aspects of learning may be unique to the human species. Cognitivism has affected educational theory by emphasizing the role of the teacher in terms of the instructor's effectiveness of presentation of instructional material in a manner that facilitates students' learning (e.g., helping students to review and connect previous learning on a topic before moving to new ideas about that topic, helping students understand the material by organizing it effectively, understanding differences in students' learning styles, etc.) [2]

\section{ACTIVITY DRIVEN TEACHING MODEL}

Institutions that teach software are responsible for producing professionals who will build and maintain systems to the satisfaction of their beneficiaries. [3]

\section{A. Training Goal}

To impart concepts of Software Project Management through a more practical approach by getting the students involved in the activities and recording their opinions. There are several concepts which are to be driven as part of the 
course curriculum. Software Project Management by Walker J. Royce is the book being followed for course curriculum. At a more mundane level, teaching software engineering also involves making the students familiar with practical techniques that have proved to be productive and are a key part of the trade.[3,4].

\section{B. Training Model}

This is an activity driven model encouraging active participation from the students. There is a topic called Barry Boehm's Staffing Principles for effective Project management in this course. The 5 principles given by Boehm called the Boehm's principles are as follows:

1. Use Fewer and Better people

2. Principle of Job Matching

3. Principle of Career Progression

4. The Principle of Team Balance

5. The Principle of Phase Out.

Instead of discussing these principles directly in the class, a teaching case has been given and students were encouraged to participate in the activity with their thoughts and suggestions as outcome of the activity.

\section{TEACHING CASE}

Your Project has been working on a new library management application for 8 months. A key individual in the project (one who is technically competent and contributed significantly to the project) is making himself unpopular with the rest of the team members by constantly referring to her importance in the success of the project. Several team members have mentioned to you that this attitude of his is beginning to annoy people so much that they are looking ways to avoid working with him. You feel that this situation has the potential to affect the success of your project.

Q1. What action would you take with the key individual himself?

Q2. What action would you take with the rest of the team?

Q3. How might you prevent similar situations from occurring?

\section{TEAM ORGANIZATION}

The entire class has been divided into 4 groups each group comprising of 15 students. Every group is encouraged to identify a group leader who is technically called the "Team Leader" for further communication. The Team Leader was the Single Point of Contact with that group. His responsibilities included collating different opinions of his team members and jotting down an optimal solution based on the team's opinions. A time slot of 20 minutes was awarded for all the groups to have a discussion and then a final discussion on the case happened for 15 minutes. All the opinions discussed were written as points on the board. After the points were noted down they were correlated to the theory explained in the text book. The students were left with a practical experience thereby making it interesting to simulate and enact several principles of Project Management.

\section{RESULT ANALYSIS}

\begin{tabular}{|c|c|c|c|c|c|}
\hline & \multicolumn{5}{|c|}{ Table 1.0} \\
\hline Sno & $Q$ & Team A & Team B & $\begin{array}{c}\text { Team } \\
\text { C }\end{array}$ & $\begin{array}{c}\text { Team } \\
\text { D }\end{array}$ \\
\hline Q1 & $\begin{array}{l}\text { What } \\
\text { action } \\
\text { would } \\
\text { you } \\
\text { take } \\
\text { with } \\
\text { the key } \\
\text { individ } \\
\text { ual } \\
\text { himself } \\
\text { ? }\end{array}$ & $\begin{array}{l}\text { Appreciate } \\
\text { the key } \\
\text { individuals } \\
\text { contributio } \\
\text { ns to the } \\
\text { project in a } \\
\text { one-to-one } \\
\text { meeting } \\
\text { (Assuming } \\
\text { that he is } \\
\text { feeling } \\
\text { that his } \\
\text { efforts not } \\
\text { being } \\
\text { given the } \\
\text { deserving } \\
\text { acclaim) }\end{array}$ & $\begin{array}{l}\text { Negotiate } \\
\text { with the } \\
\text { key } \\
\text { individua } \\
1 \text { and try } \\
\text { to } \\
\text { understan } \\
d \text { his } \\
\text { interests } \\
\text { with } \\
\text { respect to } \\
\text { career } \\
\text { progressi } \\
\text { on (lack } \\
\text { of recogniti } \\
\text { on might } \\
\text { be reason } \\
\text { for his } \\
\text { outburst) }\end{array}$ & $\begin{array}{l}\text { Counse } \\
1 \text { the } \\
\text { key } \\
\text { individ } \\
\text { ual and } \\
\text { tell him } \\
\text { the } \\
\text { importa } \\
\text { nce of } \\
\text { collecti } \\
\text { ve } \\
\text { perfor } \\
\text { mance } \\
\text { and } \\
\text { team } \\
\text { work. }\end{array}$ & $\begin{array}{l}\text { The } \\
\text { key } \\
\text { individ } \\
\text { ual } \\
\text { should } \\
\text { be } \\
\text { made } \\
\text { mentor } \\
\text { for two } \\
\text { other } \\
\text { team } \\
\text { membe } \\
\text { rs with } \\
\text { whom } \\
\text { his } \\
\text { camara } \\
\text { derie } \\
\text { works. }\end{array}$ \\
\hline $\mathrm{Q} 2$ & $\begin{array}{l}\text { What } \\
\text { action } \\
\text { would } \\
\text { you } \\
\text { take } \\
\text { with } \\
\text { the rest } \\
\text { of the } \\
\text { team? }\end{array}$ & $\begin{array}{l}\text { The other } \\
\text { team } \\
\text { members } \\
\text { should be } \\
\text { assigned } \\
\text { tasks } \\
\text { which } \\
\text { match } \\
\text { their skill } \\
\text { set and } \\
\text { encourage } \\
\text { them to } \\
\text { demonstrat } \\
\text { e tangible } \\
\text { results. }\end{array}$ & $\begin{array}{l}\text { The other } \\
\text { team } \\
\text { members' } \\
\text { aspiration } \\
\text { s should } \\
\text { be } \\
\text { individua } \\
\text { lly noted } \\
\text { down and } \\
\text { assignme } \\
\text { nts } \\
\text { should be } \\
\text { given } \\
\text { which } \\
\text { motivate } \\
\text { them. }\end{array}$ & $\begin{array}{l}\text { Respon } \\
\text { sibilitie } \\
\mathrm{s} \\
\text { should } \\
\text { be } \\
\text { divided } \\
\text { among } \\
\text { the } \\
\text { team } \\
\text { membe } \\
\text { rs } \\
\text { equally } \\
\text { and } \\
\text { individ } \\
\text { ual } \\
\text { team } \\
\text { membe } \\
\text { rs are } \\
\text { encour } \\
\text { aged to } \\
\text { contrib } \\
\text { ute to } \\
\text { the } \\
\text { team. }\end{array}$ & $\begin{array}{l}\text { The } \\
\text { other } \\
\text { team } \\
\text { membe } \\
\text { rs' } \\
\text { ideas } \\
\text { should } \\
\text { be } \\
\text { encour } \\
\text { aged } \\
\text { and } \\
\text { implem } \\
\text { ented } \\
\text { to } \\
\text { boost } \\
\text { them } \\
\text { up and } \\
\text { make } \\
\text { them } \\
\text { feel on } \\
\text { par } \\
\text { with } \\
\text { the key } \\
\text { individ } \\
\text { ual. }\end{array}$ \\
\hline
\end{tabular}


CVR Journal of Science \& Technology, Volume. 1, October 2011

\begin{tabular}{|c|c|c|c|c|c|}
\hline Q3 & $\begin{array}{l}\text { How } \\
\text { might } \\
\text { you } \\
\text { prevent } \\
\text { similar } \\
\text { situatio } \\
\text { ns from } \\
\text { occurri } \\
\text { ng? }\end{array}$ & $\begin{array}{l}\text { The team } \\
\text { should be } \\
\text { taken out } \\
\text { for team } \\
\text { outings to } \\
\text { improve } \\
\text { the } \\
\text { interperson } \\
\text { al } \\
\text { relationshi } \\
\text { ps. }\end{array}$ & $\begin{array}{l}\text { The other } \\
\text { team } \\
\text { members } \\
\text { should be } \\
\text { nominate } \\
\text { d for } \\
\text { technical } \\
\text { trainings } \\
\text { and their } \\
\text { competen } \\
\text { cy levels } \\
\text { should be } \\
\text { increased } \\
\text { to that of } \\
\text { the } \\
\text { project } \\
\text { requirem } \\
\text { ents. }\end{array}$ & $\begin{array}{l}\text { The } \\
\text { team } \\
\text { should } \\
\text { be } \\
\text { expose } \\
\text { d to } \\
\text { various } \\
\text { team } \\
\text { buildin } \\
\text { g } \\
\text { activiti } \\
\text { es like } \\
\text { outings } \\
\text { group } \\
\text { lunches } \\
\text {; } \\
\text { organiz } \\
\text { ation } \\
\text { level } \\
\text { compet } \\
\text { itions } \\
\text { etc. to } \\
\text { improv } \\
\text { e inter } \\
\text { persona } \\
1 \\
\text { relation } \\
\text { s. }\end{array}$ & $\begin{array}{l}\text { Each } \\
\text { membe } \\
\mathrm{r} \text { is } \\
\text { strong } \\
\text { at one } \\
\text { or the } \\
\text { other } \\
\text { aspects } \\
\text { and } \\
\text { each } \\
\text { person } \\
\text { should } \\
\text { be } \\
\text { made a } \\
\text { single } \\
\text { point of } \\
\text { contact } \\
\text { for } \\
\text { some } \\
\text { initiativ } \\
\text { es } \\
\text { within } \\
\text { the } \\
\text { team. }\end{array}$ \\
\hline
\end{tabular}

From the above suggestions and conclusions made by the various groups, concepts of Barry Boehm's Staffing Principles could be illustrated practically to the pupils. If similar activities can be planned for imparting the other concepts like drawbacks of classical models, improvements in the modern project management practices etc, then students are left with an enriched experience of software management concepts which will make them industry-ready.

\section{CONCLUSIONS}

An Activity driven approach not only makes the class interesting but also makes the students empathize with certain practical situations in the industry and encourage them to think proactively against amicable solutions. All students are intrinsically motivated to self actualize or learn. Similar practical situations can be picked up as cases of discussion for illustrating the importance of concepts like Identification of Metrics, Change Indicators, understanding the workflows et al. Situations of the sort heard of or imaginative can be created to make the students think and analyze situations and come up with their own thoughts which not only makes teaching SPM interesting but also helps the students visualize some of the real world scenarios.

\section{REFERENCES}

[1] Software Project Management by Walker J Royce

[2] http://teachnet.edb.utexas.edu/ Lynda_abbot/Cogni tive.html

[3] Software Engineering in the Academy- Bertrand Meyer

[4] How University Professors Teach Project Management for Information Systems- Harry L. Reif and Michel Mitri 